Yüzüncü Yil Üniversitesi
Tarim Bilimleri Dergisi

Araştırma Makalesi (Research Article)

Investigation of Drought Tolerance of Dwarf Landrace Phaseolus vulgaris L. Genotypes

Kamile ULUKAPI ${ }^{* 1}$, Ayse Gul NASIRCILAR ${ }^{2}$

${ }^{1}$ Akdeniz University, Vocational School of Technical Sciences, Organic Agriculture Program, Antalya, Turkey

${ }^{2}$ Akdeniz University, Department of Mathematics and Science Education, Faculty of Education, Antalya, Turkey ${ }^{1}$ https://orcid.org/0000-0001-8184-8967 2https://orcid.org/0000-0002-2602-804X

*Sorumlu yazar e-posta: kamileonal@akdeniz.edu.tr

\section{Article Info}

Received: 12.11 .2020

Accepted: 27.12.2020

Online Published 30.03.2021

DOI: $10.29133 /$ yyutbd.825094

Keywords

Common bean,

Drought stress,

Landrace,

Phaseolus vulgaris L.,

Stress tolerance index.

\begin{abstract}
Landrace genotypes which are important gene resources, are used as starting material in breeding studies. Common beans are sensitive to abiotic stress. For this reason, early screening tests performed under stress conditions will provide convenience for breeders to perform the breeding process accurately and fast. In this study, an early-stage drought stress index was formed for fifteen genotypes whose salt tolerance indices were determined previously. For this purpose, genotypes were exposed to four different drought stresses until the first flowering period [25\% $\left(\mathrm{I}_{25}\right), 50 \%\left(\mathrm{I}_{50}\right), 75 \%\left(\mathrm{I}_{75}\right)$, and 100\% $\left.\left(\mathrm{I}_{100}\right)\right]$. As droughtrelated plant growth parameters to determine the drought adaptability of genotypes; shoot length $(\mathrm{cm})$, root length $(\mathrm{cm})$, shoot fresh and dry weight $(\mathrm{g})$, root fresh and dry weight $(\mathrm{g})$, leaf width and length $(\mathrm{cm})$, stem diameter $(\mathrm{cm})$ and stomatal conductance were measured. Later, genotypes were classified according to the drought stress index. It was determined that genotypes and drought stress had a statistically significant effect on all parameters examined, and Genotype $x$ Drought interaction for all properties to be significant at the 0.01 level. According to the drought stress index data, three of the genotypes (ADY4, AGB1 and AGB5) were moderately sensitive and twelve (AGun6, AGun19, AGun25, BKara1-A, Bkara2, BY4, BY24, ISGa1, ISGa7, ISGa10, IYoz10 and IYoz14) were sensitive. In conclusion, although the studied genotypes were not drought tolerant, this was determined in the early stage using the drought tolerance index. This study is important as an example of the early classification of vegetable genotypes using drought tolerance indexes in future studies.
\end{abstract}

\title{
Bodur Yerel Fasulye Genotiplerinin Kuraklık Stresine Tolerans Düzeylerinin Araştırılması
}

\section{Makale Bilgileri}

Geliş: 12.11 .2020

Kabul: 27.12.2020

Online Yayınlanma 30.03.2021

DOI: 10.29133/yyutbd.825094

\section{Anahtar kelimeler}

Fasulye,

Kuraklık stresi,

Yerel çeşit,

Phaseolus vulgaris L.,
Öz: Önemli gen kaynağı olan yerel çeşitler, ıslah çalışmalarında başlangıç materyali olarak kullanılmaktadır. Fasulye abiyotik strese duyarlı bir türdür. Bu nedenle stres koşullarında yapılan erken tarama testleri ıslah sürecinin doğru ve hızlı olarak yapılabilmesi için ıslahçılara kolaylık sağlayacaktır. Bu çalışmada, tuz tolerans indeksleri önceden belirlenmiş on beş genotip için erken dönem kuraklık stresi indeksi oluşturulmuştur. Bu amaçla genotipler ilk çiçeklenme dönemine kadar dört farklı kuraklık stresine maruz bırakılmıştır [\%25 ( $\left.\mathrm{I}_{25}\right)$, \%50 ( $\left.\mathrm{I}_{50}\right)$, \%75 $\left(\mathrm{I}_{75}\right)$ ve \%100 $\left.\left(\mathrm{I}_{100}\right)\right]$. Genotiplerin kuraklık adaptasyonunu belirlemek için kuraklıkla ilişkili bitki büyüme parametreleri olarak; sürgün uzunluğu $(\mathrm{cm})$, kök uzunluğu (cm), sürgün yaş ve kuru ağırlığı $(\mathrm{g})$, kök yaş ve kuru ağırlığ $(\mathrm{g})$, yaprak genişliği ve uzunluğu $(\mathrm{cm})$, gövde çapı $(\mathrm{cm})$ ve stomatal iletkenlik ölçülmüştür. Daha sonra genotipler kuraklık stres indeksine göre 
sınıflandırılmıştır. Genotiplerin ve kuraklık stresinin incelenen tüm parametreler üzerinde istatistiksel olarak anlamlı bir etkiye sahip olduğu ve tüm özellikler için Genotip x Kuraklık etkileşiminin 0.01 düzeyinde anlamlı olduğu belirlenmiştir. Elde edilen kuraklık stresi indeksi verilerine göre genotiplerin üçünün (ADY4, AGB1 ve AGB5) orta derecede duyarl1, on iki tanesinin ise (AGun6, AGun19, AGun25, BKara1-A, Bkara2, BY4, BY24, ISGa1, ISGa7, ISGa10, IYoz10 ve IYoz14) duyarlı olduğu belirlenmiştir. Sonuç olarak, çalışılan genotipler kuraklığa tolerant olmamakla birlikte bu durum kuraklık tolerans indeksi kullanılarak erken dönemde belirlenmiştir. Bu çalışma seleksiyon indeksleri kullanılarak farklı sebze genotiplerinin erken dönemde sinıflandırılmasına bir örnek oluşturması açısından önem taşımaktadır.

\section{Introduction}

Common bean is a very important crop in terms of its contribution to sustainable agriculture and human nutrition (Önder et al., 2012). Changing climatic conditions necessitate the expansion of the existing gene pool and the identification of the characteristics of landrace genotypes, and the inclusion of these genotypes in future breeding programs. Drought is an important stress factor limiting common bean production. Although different methods are applied to minimize the effects of drought stress, the most basic and permanent solution is to produce with drought-tolerant varieties. For this purpose, determining the tolerance levels of landrace varieties that are important gene sources is an effective method for common beans that already have a narrow genetic diversity because of self-pollination. The drought problem, which directly affects two billion people worldwide and occurs as a result of climate changes, has more severe effects on common beans than other abiotic stress factors and affects $60 \%$ of bean production areas (Mortimore, 2005; Beebe et al., 2008; Asfaw and Blair, 2014).

Different morphological and physiological parameters are used to determine drought-tolerant genotypes. Photosynthesis, one of these, is the most fundamental physiological process affected by drought. In connection with photosynthesis, stomatal conductivity is also reported to be an important parameter in terms of being affected by drought stress. Increasing carbon dioxide fixation as a consequence of stomatal conductivity ensures that plants are less affected by drought. Shoot and root properties are some of the characters that can be used to determine drought tolerance. Fresh and dry weights of vegetative organs such as roots and shoots are also parameters used for this purpose. Plants have developed some adaptation mechanisms to avoid drought. In common beans, increasing the root length, minimizing water loss by decreasing the leaf area are some of the strategies developed for this purpose (Blum, 2009; Beebe et al., 2013; Assefa et al., 2015; Lanna et al., 2016). In many studies, stress selection indices have been used to measure the effects of drought stress on common beans and to compare varieties (Darkwa et al., 2016; Dipp et al., 2017; Sánchez-Reinosoet et al., 2020). The stress tolerance index is a quick and easy method for selecting genotypes that are tolerant to stress conditions (Negrão et al., 2017). The most important advantage of this method, which is formed according to the degree of suppression in vegetative growth parameters due to stress, is that it can perform very well in tolerant genotype selection.

In recent years, climate change, which has become more effective day by day, has highlighted the tolerance to abiotic stress conditions. The fact that material exchange through gene banks is a topical issue to develop new varieties in the globalizing world requires screening genetic resources for sustainable agriculture. However, the field trials for drought screening of genotypes are difficult due to the variability of climatic conditions, the inhomogeneity of the soil structure, and the increased need for time and labor owing to the use of a large number of plant materials (Ahmad et al., 2009). Selecting the appropriate genotypes by using selection indices in the early stage will make it facilitate breeders as it will save time and cost. In this study, planned from this point, it was aimed to determine the response of fifteen landrace common bean genotypes to drought stress by using vegetative growth data and stomatal conductivity which are parameters related to drought stress and to early-stage classify genotypes according to drought tolerance indexes. 


\section{Materials and Methods}

\subsection{Plant material and growing conditions}

The research was carried out in the unheated greenhouse of Akdeniz University Vocational School of Technical Sciences, Department of Plant and Animal Production in 2018 April-May. According to long-year data, the average temperatures in April and May of Antalya are 16.3 and $20.5^{\circ} \mathrm{C}$ In the study, fifteen landrace common bean genotypes collected from Antalya, Burdur, and Isparta provinces of the Western Mediterranean Region of Turkey were used. All genotypes were dwarf growth habit.

$4.2 \mathrm{l}$ plastic pots of $20 \mathrm{x} 18 \mathrm{~cm}$ were used as plant growing medium in the study. Common bean genotypes were grown by direct seed sowing in pots containing a mixture of peat + perlite (1: 1). The experiment was carried out according to the randomized complete block design in four replicates, with three pots for each repetition. Twelve plants were included for each application.

\subsection{Drought stress application}

Different drought levels were applied after the plants reached the period with 3-4 leaves. The required irrigation water for the seedlings in plastic pots was periodically weighted every 2-3 days on a weight basis, and the reduced amount was filled. Stress application continued until the flowering period. Fifteen common bean genotypes were grown in four different irrigation (I) regimes; non-stress $\left(\mathrm{I}_{100}\right.$ : $100 \%)$, mild stress ( $\left.I_{75}: 75 \%\right)$, moderate stress ( $\left.I_{50}: 50 \%\right)$, severe stress $\left(I_{25}: 25 \%\right)$.

\subsection{Drought tolerance index}

The following formulas are used to determine stress tolerance indices (Ashraf et al., 2006):

$$
\text { Plant height stress index }=\left(\frac{\text { Plant height of stressed plant }}{\text { Plant height of control plants }}\right) \times 100
$$

$$
\text { Plant root stress index }=\left(\frac{\text { Root length of stressed plant }}{\text { Root length of control plants }}\right) \times 100
$$

$$
\text { Dry matter stress index }=\left(\frac{\text { Dry matter of stressed plant }}{\text { Dry matter of control plants }}\right) \times 100
$$

Stress tolerance index calculations were made using 25\% (severe drought) and 100\% (optimum irrigation level) values. The drought stress index was obtained by averaging the index data given above formulas. Genotypes were classified using standard mean errors of these data (Al-Ashkar and El-Kafafi 2014). The formula used by Al-Ashkar and El-Kafafi (2014) for the salt tolerance index has been adapted to the drought tolerance index. The classification was divided into four groups as drought tolerant, moderately tolerant, moderately sensitive, and sensitive.

\subsection{Measurement in genotypes and statistical analysis}

In the genotypes harvested after the first flowering; shoot length $(\mathrm{cm})$, root length (cm), shoot fresh and dry weight (g), root fresh and dry weight (g), leaf width and length (cm), and stem diameter (cm) were measured. Stomatal conductance was measured using the Decagon SC-1 Leaf Porometer (Decagon Devices, Inc., Pullman, Washington) on the abaxial surface of the ear leaf as mmol m $\mathrm{m}^{-2} \mathrm{~s}^{-1}$. The measurements were carried out in full clear air conditions between $11.00 \mathrm{am}$ and $02.00 \mathrm{pm}$.

A total of 10 parametric characters were measured to determine the vegetative development of plants under stress conditions. These measurements were made using a ruler, digital caliper, tape measure, and weighing machine (0.0001). Descriptive statistics, Principal Component Analysis (PCA), regression, and clustering analyses were performed with Minitab 17.0 statistical software. 


\section{Results}

\subsection{The effect of drought stress on vegetative growth parameters}

The results of variance analysis regarding vegetative growth parameters (shoot and root length, leaf length and width, root and shoot fresh and fresh weight, stem diameter) and stomatal conductance of landrace common bean genotypes grown in different drought levels were given in Table 1 . According to these data, a significant correlation at the $\mathrm{p}<0.01$ level was found between all parameters examined. Genotypes and drought stress have been found to be a source of diversity. In the interactions between the sources of variation, it was determined that the G X D interaction was significant at the 0.01 level in all parameters.

Table 1. Variance analysis results with respect to vegetative parameters and stomatal conductivity of landrace common bean genotypes under drought stress

\begin{tabular}{llllllllllll}
\hline Variation sources & df & SD & LW & LL & RL & SL & SFW & RFW & SDW & RDW & SC \\
\hline Genotyes (C) & 14 & $*$ & $*$ & $*$ & $*$ & $*$ & $*$ & $*$ & $*$ & $*$ & $*$ \\
Drought (D) & 3 & $*$ & $*$ & $*$ & $*$ & $*$ & $*$ & $*$ & $*$ & $*$ & $*$ \\
G*D & 42 & $*$ & $*$ & $*$ & $*$ & $*$ & $*$ & $*$ & $*$ & $*$ & $*$ \\
\hline
\end{tabular}

SD: Stem diameter, LW: Leaf width, LL: Leaf length, RL: Root length, SL: Shoot length, SFW: Shoot fresh weight, RFW: Root fresh weight, SDW: Shoot dry weight, RDW: Root dry weight, SC: Stomatal conductance, * Significant at p $<0.01$.

The correlation among vegetative parameters and stomatal conductance under drought stress was given in Figure 2. The important correlations detected can be listed as follows: between leaf width and shoot dry weight $(\mathrm{r}=0.617)$, root dry weight $(\mathrm{r}=0.535)$; between leaf length and shoot length $(\mathrm{r}=0.532)$, shoot dry weight ( $\mathrm{r}=0.552)$; also, between shoot length and shoot dry weight $(\mathrm{r}=0.588)$; between shoot fresh weight and shoot dry weight $(\mathrm{r}=0.539)$; between stem diameter and shoot fresh weight ( $\mathrm{r}=0.583)$; between root fresh weight and shoot dry weight $(\mathrm{r}=0.558)$. It was determined that there is a statistically positive strong relationship between leaf width and leaf length $(\mathrm{r}=0.868)$, as well as between root fresh weight and root dry weight $(\mathrm{r}=0.760)$. It was found that negative correlations between parameters were not statistically significant.

Table 2. Correlations of vegetative parameters and stomatal conductance of landrace common bean genotypes under drought stress

\begin{tabular}{|c|c|c|c|c|c|c|c|c|c|}
\hline & SD & LW & LL & RL & SL & SFW & RFW & SDW & RDW \\
\hline LW & $0.385^{*}$ & & & & & & & & \\
\hline LL & $0.382 *$ & $0.868^{*}$ & & & & & & & \\
\hline RL & $0.159 * *$ & $0.021^{\text {ns }}$ & $0.101^{\text {ns }}$ & & & & & & \\
\hline SL & $0.241 * *$ & $0.392 *$ & $0.532 *$ & $0.431 *$ & & & & & \\
\hline SFW & $0.583 *$ & $0.391^{*}$ & $0.480^{*}$ & $-0.041^{\mathrm{ns}}$ & $0.407 *$ & & & & \\
\hline RFW & 0.383* & $0.429 *$ & $0.328 *$ & $-0.035^{\mathrm{ns}}$ & $0.194 * *$ & $0.399 *$ & & & \\
\hline SDW & $0.237 * *$ & $0.617^{*}$ & $0.552 *$ & $0.119^{\text {ns }}$ & $0.588 *$ & $0.539 *$ & $0.558 *$ & & \\
\hline RDW & $0.436 *$ & $0.535^{*}$ & $0.418^{*}$ & $-0.080^{\text {ns }}$ & $0.230 * *$ & $0.188^{* *}$ & $0.760^{*}$ & $0.349 *$ & \\
\hline SC & $0.374^{*}$ & $0.281^{*}$ & $0.326^{*}$ & $-0.105^{\mathrm{ns}}$ & $-0.036^{\mathrm{ns}}$ & $0.321 *$ & $-0.044^{\mathrm{ns}}$ & $-0.032^{\mathrm{ns}}$ & $0.153^{* *}$ \\
\hline
\end{tabular}

* Significant at $\mathrm{p}<0.01$, ** Significant at $\mathrm{p}<0.05$, ns: not significant.

The effects of drought stress on genotypes and interactions are given in Figure 1. Drought stress negatively affected all parameters. As seen in Figure 1, it has been determined that increasing the irrigation level enhances the values of all parameters and promotes plant growth. However, the stem diameter did not differ between $\mathrm{I}_{75}$ and $\mathrm{I}_{100}$ irrigation levels, and the rising irrigation level did not statistically affect the stem diameter. This increase varied according to genotypes. In terms of root development, which is an important index in tolerance to drought, AGB1 (2) and AGB5 (3) genotypes have the highest root length, while genotype BY-4 (9) has the lowest root length. While other genotypes gave very variable results in root dry and fresh weight, the ADY4 (1) genotype come into prominence with its high values. Besides, genotypes varied in other parameters, and this variability was also seen 
depending on the genotypes in the G X D interaction. As can be seen in Figure 1, it was determined that ISGA-7 (14) did not interact with drought stress in terms of stomatal conductivity.

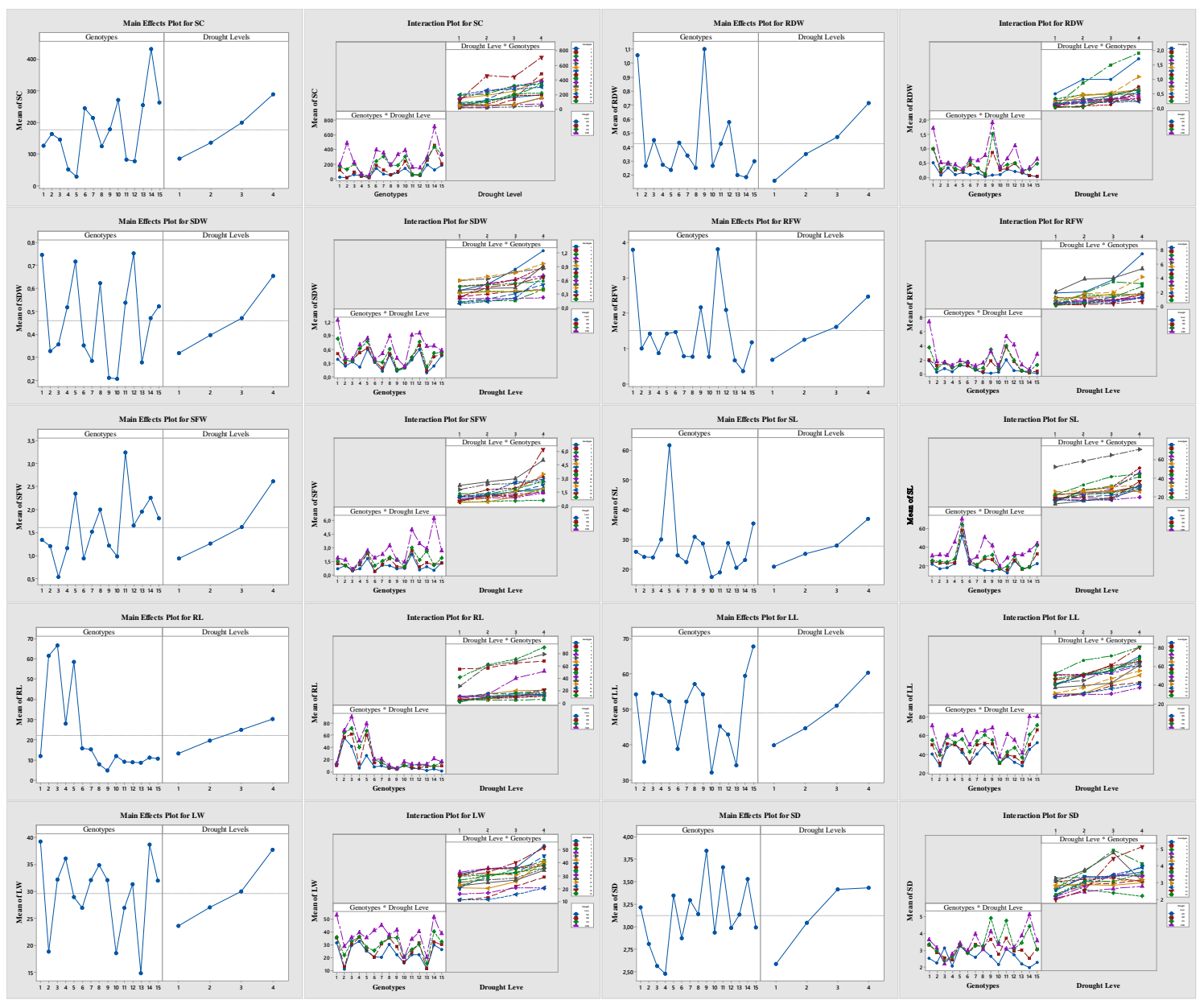

Figure 1. Main effects of genotypes and drought levels on plant growth parameters and stomatal conductance and graphical expression of interactions between cultivars and drought stress levels.

\subsection{Classification of genotypes according to drought tolerance index}

Classification of genotypes according to drought tolerance index is given in Table 3. DTI based on vegetative growth parameters varied a range of $24 \%$ to $63 \%$. According to DTI data, the genotypes were classified into four groups: tolerant (84\% and above), moderately tolerant (68-83\%), moderately sensitive (52-67\%), and sensitive (below 51\%) (Table 3). It was determined that there was no tolerant and moderately tolerant genotype among the fifteen genotypes exposed to drought stress. Three of these genotypes ADY4 (1), AGB1 (2), AGB5 (3) were determined as moderately sensitive, and twelve as sensitive.

The principal component analysis (PCA) was performed using a variable the DTI parameters of the genotypes under drought stress conditions and the dendrogram was formed using the DTI parameters (Figure 2). Genotypes were divided into two main groups according to the dendrogram. Although moderately sensitive genotypes were in the same group, there were also sensitive genotypes in this group. This was due to the proximity of the DTI data to each other, and the separation of genotypes is more clearly seen in the PCA analysis. Genotypes with very low DTI values (30\% and below) formed the second group. As seen in the cluster of the genotypes and the PCA distribution, the two moderately sensitive genotypes ADY4 (61.30), AGB1 (62.71) which had the highest DTI data were completely separated from the other genotypes. The other moderately sensitive AGB5 (55.95) clustered close to these genotypes, but also near to the BKARA-2 (51.56) genotype which had a close DTI value. 
Table 3. Drought tolerance categories of landraces common bean genotypes on the basis of drought tolerance index

\begin{tabular}{llll}
\hline $\begin{array}{l}\text { Drought Tolerance } \\
\text { Category }\end{array}$ & Range of STI & $\begin{array}{l}\text { Number of } \\
\text { Genotypes }\end{array}$ & Name of Landrace Common Bean Genotypes \\
\hline $\begin{array}{l}\text { Tolerant } \\
\text { Moderately } \\
\text { tolerant }\end{array}$ & $\begin{array}{l}\% 84 \text { and above } \\
68-83 \%\end{array}$ & & \\
$\begin{array}{l}\text { Moderately } \\
\text { sensitive }\end{array}$ & $52-67 \%$ & 3 & ADY4 (1), AGB1 (2), AGB5 (3), \\
$\begin{array}{l}\text { Sensitive } \\
\text { Below 51\% }\end{array}$ & 12 & $\begin{array}{l}\text { AGUN6, AGUN19, AGUN25, BKARA1-A, } \\
\text { BKARA2, BY4, BY24, ISGA1, ISGA7, ISGA10. } \\
\text { IYOZ10. IYOZ4 }\end{array}$ \\
\hline
\end{tabular}
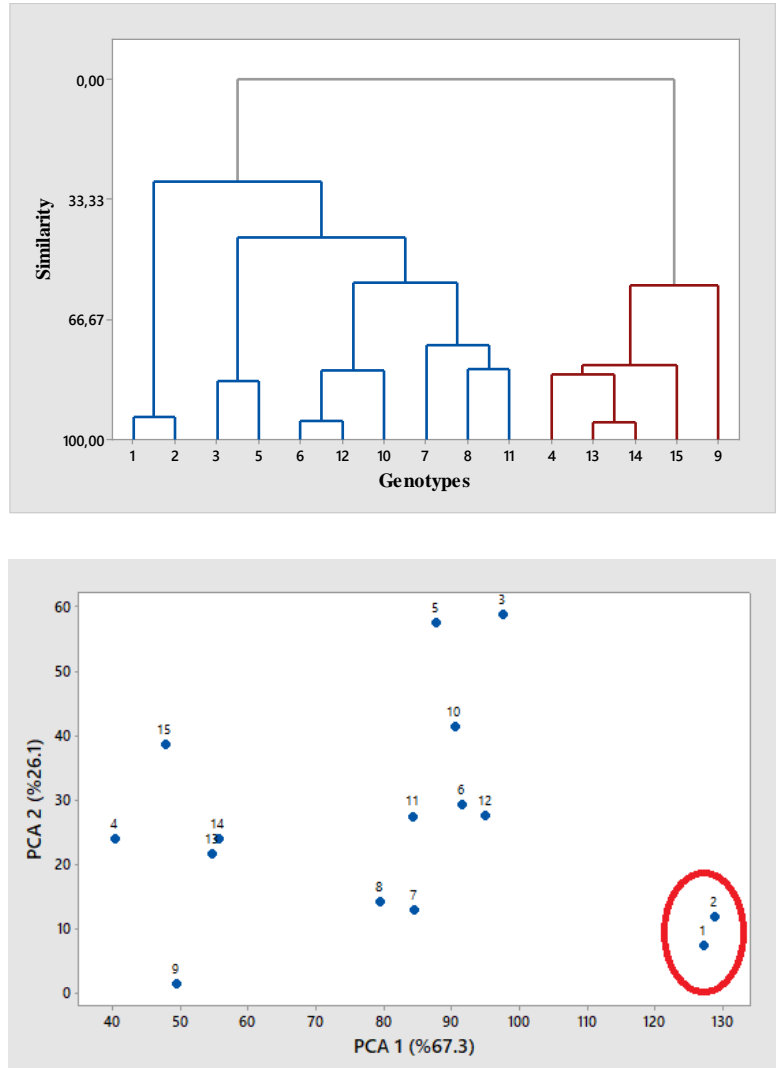

Figure 2. Principal Component Analysis of the distribution of landrace genotypes (right) and dendrogram (left).

PCA1 explained $67.3 \%$ of the variation between genotypes and consisted of RL-SI (0.720), PHSI (0.468). PCA2 explained 26.1\% of the variation and PDW-SI (0.910) was the effective parameter. According to the PCA data, it was determined that the effective parameters in water stress are the stress index based on root length and plant length.

\section{Discussion and Conclusion}

The negative effect of drought stress on plants varies according to the time, the severity of the drought, and genotype and indicate its negative effects in all stages of the plants (Mizgin et al., 2019; Khanzada et al., 2020). It has been demonstrated by different studies that drought stress affects parameters such as total biomass and seed yield, number of seeds and pods per plant, root length in common bean (Asfaw et al., 2012; Asfaw and Blair, 2014). In this study, the decrease in vegetative growth of genotypes increased due to the rise in stress levels. Developing new drought tolerant varieties or screening existing gene resources is a costly process that requires a long time and effort in field 
conditions. Stress tolerance index, which is based on the negative effects of stress conditions on vegetative growth, is a fast, easy, applicable, and effective method and is commonly used in field crops (Ahmad et al., 2009; Saima et al., 2018; Khanzada et al., 2020). However, it is used limitedly in vegetable species whose breeding takes years. Plants need water to maintain their metabolic activities, to take in plant nutrients and specially to perform photosynthesis. The rate of water decreased due to drought firstly affects the vegetative growth parameters of the plants and are observed some morphological changes. These processes occurring in plant physiology were also identified in the genotypes in this study. Depending on the continuation of the drought stress, some biochemical activities, and changes in the expression of stress-related genes occur in the plant. Stress factors cause permanent changes in gene expressions through epigenetic mechanisms without a change in the nucleotide sequences in the genome (Jaleel et al., 2009; Farooq et al., 2012; Verslues et al., 2014; SalehiLisar and Bakhshayeshan-Agdam 2016; Neves et al., 2017; Raza et al., 2019). In this study, drought stress was terminated after the first flowers were seen. The purpose of this is that genotypes can be evaluated not only in seedling development but also in more advanced stages of vegetative development. Thus, it was determined to what extent plant growth was affected by stress during the vegetative period. All parameters of common bean genotypes were negatively affected under stress conditions, and it was determined that there was genotype, drought, and G x D interaction for all parameters. As seen in Figure 2 , the rise in the irrigation level has increased the growth parameters. This effect was more clearly seen when the irrigation level was increased to the level of $\mathrm{I}_{100}$. However, there was no statistically significant difference in $\mathrm{I}_{100}$ and $\mathrm{I}_{75}$ irrigation issues in stem diameter. Khanzada et al (2020) reported that the effect of drought on root development is important in Brassica napus. In this study, the ADY4 genotype determined as moderate sensitive and having the highest index values was the least affected genotype in terms of root fresh and dry weight. The fact that AGB1 in the same classification is the least affected genotype in terms of root length also supports the effect of root development on drought tolerance. The root length during the seedling period can be informative about adaptation to drought (Rehman et al., 2015).

It was found that the variation among the parameters examined was quite high according to genotypes. DTI values of root length (81.15-9.46), plant length (68.69-30.00), and plant dry weight (73.34-9.15) showed wide variation. This situation was reflected in the total DTI values, and a range from 62.71 to 23.52 was determined. These results are an indicator of the differences in the drought exposure levels of genotypes. Khanzada et al. (2020) also obtained a wide variation in wheat for drought tolerance, and it was reported that the data of different indexes providing high-quality data for phenotyping were supported by SNP marker analysis. In the cluster analysis of genotypes according to the DTI data obtained, while ADY4 and AGB1 genotypes were grouped differently from the others, AGB5 in the same tolerance category was the closest classified genotype. Variation in early-stage plant development is a reliable source of information for screening large numbers of plants for drought tolerance (Saima et al., 2018; Khanzada et al., 2020). Consistent with this study, there are many studies revealing the reduction and variation in plant development due to drought stress (Shamim et al., 2014; Saima et al., 2018; Sallam et al., 2018; Khanzada et al., 2020). In determining the drought tolerance in the early seedling stage, the indexes obtained by considering different criteria instead of a single criterion are a very effective method in determining the tolerance to stress (Sallam et al., 2018).

Because drought tolerance and salinity tolerance share to some extent the osmotic adjustment mechanism, salt and drought tolerance in common beans are parallel (Asraf and Imran, 2015). In a study conducted by Ulukapi (2020), the genotypes used in this study were screened using salt tolerance index in terms of tolerance to salt stress and molecularly characterized. Similar to the results of this study, it was determined that there was no genotype with salt tolerance among the genotypes showing dwarf growth habit among all the genotypes examined. This situation was explained by the quite limited sharing of alleles of the climbing and dwarf genotypes as a result of molecular analysis. The stress tolerance index used in both studies was effective in the separation of genotypes. The coherence of the results and their molecular support showed that DTI analysis which is examining complex stress-related vegetative relationships is both reliable and can be easily used in breeding studies. 


\section{References}

Ahmad, S., Ahmad, R., Ashraf, M. Y., Ashraf, M., \& Waraich, E. A. (2009). Sunflower (Helianthus annuus L.) response to drought stress at germination and seedling growth stages. Pakistan Journal of Botany, 41(2), 647-654.

Al-Ashkar, I. M, \& El-Kafafi, S. H. (2014). Identification of traits contributing salt tolerance in some doubled haploid wheat lines at seedling stage. Middle East Journal of Applied Sciences, 4(4), 1130-1140.

Asfaw, A. \& Blair, M. W. (2014). Quantification of drought tolerance in Ethiopian common bean varieties. Agricultural Sciences, 5, 124-139.

Asfaw, A., Almekinders, C., Blair, M. W., \& Struik, P. (2012.) Participatory approach in common bean breeding for drought tolerance for southern Ethiopia. Plant Breeding, 131, 125-134.

Ashraf, M. \& Iram, A. (2005). Drought stress induced changes in some organic substances in nodules and other plant parts of two potential legumes differing in salt tolerance. Flora, 200. 535-546.

Ashraf, M.Y., K. Akhtar, F. Hussain \& J. Iqbal. (2006). Screening of different accessions of three potential grass species from Cholistan desert for salt tolerance. Pakistan Journal of Botany, 38, 1589-1597.

Assefa, T., Wu, J., Beebe, S. E., Rao, I. M., Marcomin, D. \& Claude, R. J. (2015). Improving adaptation to drought stress in small red common bean: phenotypic differences and predicted genotypic effects on grain yield, yield components and harvest index. Euphytica, 203 (3), 477-489.

Beebe, S. E., Rao, I. M., Cajiao, V. \& Grajales, M. (2008). Selection for drought resistance in common bean also improves yield in phosphorus limited and favorable environments. Crop Science, 48:582-592.

Beebe, S. E., Rao, I. M., Blair, M. W. \& Acosta-Gallegos, J. A. (2013). Phenotyping common beans for adaptation to drought. Frontiers in Physiology, 4, 35.

Blum, A. (2009). Effective use of water (EUW) and not water-use efficiency (WUE) is the target of crop yield improvement under drought stress. Field Crops Research, 112(2), 119-123.

Darkwa, K., Ambachew, D., Mohammed, H., Asfaw, A., \& Blair, M. W. (2016). Evaluation of common bean (Phaseolus vulgaris L.) genotypes for drought stress adaptation in Ethiopia. The Crop Journal, 4(5), 367-376.

Dipp, C. C., Marchese, J. A., Woyann, L. G., Bosse, M. A., Roman, M. H., Gobatto, D. R., \& Finatto, T. (2017). Drought stress tolerance in common bean: what about highly cultivated Brazilian genotypes?. Euphytica, 213(5), 102.

Farooq, M., Hussain, M., Wahid, A., \& Siddique, K. H. M. (2012). Drought stress in plants: an overview. In Plant responses to drought stress (pp. 1-33). Springer, Berlin, Heidelberg.

Jaleel, C. A., Manivannan, P., Wahid, A., Farooq, M., Al-Juburi, H. J., Somasundaram, R. \& Panneerselvam, R. (2009). Drought stress in plants: a review on morphological characteristics and pigments composition. International Journal of Agriculture \& Biology, 11(1), 100-105.

Khanzada, H., Wassan, G. M., He, H., Mason, A. S., Keerio, A. A., Khanzada, S., \& Huang, Y. (2020). Differentially evolved drought stress indices determine the genetic variation of Brassica napus at seedling traits by genome-wide association mapping. Journal of Advanced Research, 24, 447461.

Lanna, A. C., Mitsuzono, S. T., Terra, T. G. R., Vianello, R. P. \& de Figueiredo Carvalho, M. A. (2016). Physiological characterization of common bean (Phaseolus vulgaris L.) genotypes, water-stress induced with contrasting response towards drought. Australian Journal of Crop Science, 10(1), 1.

Mizgin, B., Tunçtürk, R. \& Tunçtürk, M. (2019). Kurakl1k stresi altındaki ekinezya (Echinacea purpurea L.)'da deniz yosununun büyüme parametreleri, toplam fenolik ve antioksidan madde üzerine etkisi. Yüzüncü Yll Üniversitesi Tarım Bilimleri Dergisi, 29(3), 496-505.

Mortimore, M. (2005). Ecosystems and Human Well-being: Current State and Trends. (Current State ve Trends Assessment-Chapter 22, Millennium Ecosystem Assessment: Ed. Anderson, S., Cotula, L., Faccer, K., Hesse, C., Mwangi, A., Nyangena, W., Skinner, J. p, 139. ISBN 1-59726040-1.

Negrão, S., Schmöckel, S. M. \& Tester M. (2017). Evaluating physiological responses of plants to salinity stress. Annals of botany, 119(1), 1-11. 
Neves, D. M., da Hora Almeida, L. A., Santana-Vieira, D. D. S., Freschi, L., Ferreira, C. F., dos Santos Soares Filho, W., \& da Silva Gesteira, A. (2017). Recurrent water deficit causes epigenetic and hormonal changes in citrus plants. Scientific reports, 7(1), 1-11.

Önder, M., Ateş, M. K., Kahraman, A., \& Ceyhan, E. (2012). Konya ilinde fasulye tarımında karşılaşılan problemler ve çözüm önerileri. International Journal of Agricultural and Natural Sciences, 5(1), 143-148.

Raza, A., Razzaq, A., Mehmood, S. S., Zou, X., Zhang, X., Lv, Y., \& Xu, J. (2019). Impact of climate change on crops adaptation and strategies to tackle its outcome: A review. Plants, 8(2), 34.

Rehman, A., Jingdong, L., Shahzad, B., Chandio, A. A., Hussain, I., Nabi, G., \& Iqbal, M. S. (2015). Economic perspectives of major field crops of Pakistan: An empirical study. Pacific Science Review B: Humanities and Social Sciences, 1(3), 145-158.

Saima, S., Li, G., \& Wu, G. (2018). Effects of drought stress on hybrids of Vigna radiata at germination stage. Acta Biologica Hungarica, 69(4), 481-492.

Salehi-Lisar, S. Y., \& Bakhshayeshan-Agdam, H. (2016). Drought stress in plants: causes, consequences, and tolerance. In Drought Stress Tolerance in Plants, Vol 1 (pp. 1-16). Springer, Cham.

Sallam, A., Mourad, A. M., Hussain, W. \& Baenziger, P. S. (2018). Genetic variation in drought tolerance at seedling stage and grain yield in low rainfall environments in wheat (Triticum aestivum L.). Euphytica, 214(9), 169.

Sánchez-Reinoso, A. D., Ligarreto-Moreno, G. A., \& Restrepo-Díaz, H. (2020). Evaluation of drought indices to identify tolerant genotypes in common bean bush (Phaseolus vulgaris L.). Journal of Integrative Agriculture, 19 (1), 99-107.

Shamim, F., Farooq, K., \& Waheed, A. (2014). Effect of different water regimes on biometric traits of some tolerant and sensitive tomato genotypes. The Journal of Animal and Plant Science, 24(4), 1178-1182.

Ulukapi, K. (2020). Assessment of the Genetic Structure and Salt Tolerance of Phaseolus vulgaris L. Landraces. SABRAO Journal of Breeding \& Genetics, 52(3), 271-291.

Verslues, P. E., Lasky, J. R., Juenger, T. E., Liu, T. W. \& Kumar, M. N. (2014). Genome-wide association mapping combined with reverse genetics identifies new effectors of low water potential-induced proline accumulation in Arabidopsis. Plant Physiology, 164, 144-159. 